\title{
THERMOLUMINESCENT DATING OF THE LATE BRONZE AND EARLY IRON AGE POTTERY ON SITES IN KŁYŻÓW AND JAROSŁAW (SE POLAND)
}

\author{
SYLWESTER CZOPEK ${ }^{1}$, JAROSŁAW KUSIAK ${ }^{2}$ and KATARZYNA TRYBALA-ZAWIŚLAK ${ }^{\mathbf{1}}$ \\ ${ }^{1}$ Institute of Archaeology, University of Rzeszów, Hoffmanowej 8, 35-016 Rzeszów, Poland \\ ${ }^{2}$ Department of Geoecology and Palaeogeography, Maria Curie-Skłodowska University, Al. Kraśnicka 2 cd, 20-718 Lublin, Poland
}

Received 29 March 2012 Accepted 2 November 2011

\begin{abstract}
The absolute chronology of Late Bronze and Early Iron Ages in Polish territories is a result of long-term and complex research. Here, we have investigated the absolute dating of two sites, namely Kłyżów, a cemetery of the Tarnobrzeg Lusatian culture, and Jarosław, a settlement spanning from the late phase of the former to Pomeranian culture, possibly with Jastorf elements. Having been spurred by promising results of thermoluminescence (TL) dating of medieval and Przeworsk materials, we have employed it in those situations, where no other chronometric methods seem to be efficient. TL dating has been combined with typological analysis of the dated pottery and, partially, with radiocarbon method. Albeit the produced TL dates do not represent the level of sought-for fine chronological resolution, they indicate the temporal trends and corroborate the typological research. Our study has shown the potential of TL dating for periods with plateaus on ${ }^{14} \mathrm{C}$ calibration curve. We also have dealt with unexpected TL ages and suggested some solutions of the problem. Finally, we have demonstrated that the condition sine qua non for archaeological interpretation of TL dates is a thorough stylistic-chronological analysis of dated pottery and clear understanding of relations between chronometric dates and the archaeological event to be dated.
\end{abstract}

Keywords: TL dating, Early Iron Age, Tarnobrzeg Lusatian culture, Pomeranian culture.

\section{INTRODUCTION}

Previous absolute dating of the Late Bronze and Early Iron Age in Polish territories requires fairly intensive research. It is clearly visible when we compare European arrangements (see e.g. Trachsel, 2004) with still in use (see Gedl 1989; Dąbrowski 2009) chronological scheme proposed by Kostrzewski (1949, chronological table). It is also difficult to consider the state of publications and materials to be satisfactory, even though they discuss the need to work on the absolute chronology of the discussed

Corresponding author: J. Kusiak

e-mail:kusiak@umcs.pl chronological range. It is a vast difference in relation to other prehistoric periods. Moreover, it is a common fact that producing chronometric dates is not very useful for materials of the Late Bronze and Early Iron Age. This belief may well be rooted in the fact that employment of radiocarbon dating in periods typical with low-gradient portions of calibration curve is inefficient. For instance, for the time-window corresponding to the Early Iron Age we encounter the Hallstatt plateau that makes calibration of individual radiocarbon dates ambiguous (see e.g. Czopek and Poradyło 2008; Walanus and Goslar 2009). Therefore, it was decided to establish dates using the TL method, particularly if we consider it in the context of the 
promising results obtained for the Early Medieval and Przeworsk materials (Buko et al., 2008; Kusiak et al., 2011). Taking the subject of absolute dating of materials and associated archaeological contexts is essential for the synchronization of the two great provinces of the early Iron Age culture - Hallstatt (Western) and Scythian (Eastern). It were these provinces that influenced the area of the present-day Poland. The south-eastern region was at the time $\left(9^{\text {th }} / 8^{\text {th }}-3^{\text {rd }}\right.$ century BC) mainly under the influence of Eastern European cultural centers, for which the basic chronological system is historical dating - the use of an absolute time scale. On the contrary, the chronological system for Central Europe is based on the variety of forms of particular artefacts which are assigned to narrower stages of relative chronology. If there is no possibility to compare inventories (other types of artefacts), the absolute chronology remains to be the only method of comparison. Therefore, the study of the chronology of materials from south-eastern Poland is highly important, since at the moment we use the establishments that are not very precise - they have remained almost unchanged since the 1960 's. It seems that it is a major problem at least in the area of the Central Europe. Due to the lack of other absolute dating options, the role of the most common archaeological source - ceramics (as a potential material for the absolute dating) rises. The researchers selected two sites for dating - a cemetery of the Tarnobrzeg Lusatian culture in Kłyżów, dist. Stalowa Wola, site 2 (Fig. 1) and a multicultural settlement from the site 158 in Jarosław, dist. loco (Fig. 2). These two sites chosen for the research were containing very important archaeological materials, implying both the eastern influence (Kłyżów) and the relationships with other provinces (Jaroslaw). Another argument was the functional diversity of the sites - settlement (Jarosław) and cemetery (Kłyżów), as well as a relatively full chronological range, referring to nearly whole of the early Iron Age (Tarnobrzeg Lusatian culture and Pomeranian culture).

Using the phenomenon of thermoluminescence for age determination in geology and archaeology was proposed by Daniels et al. (1953) in the journal Science. The first dates for ceramic samples were published by Grögler et al. in 1958. In case of ceramics, the TL method allows us to specify the time range that has elapsed since the last heating to a temperature of at least $500^{\circ} \mathrm{C}$. Comparing with other absolute dating methods, it is distinctive because the obtained age is given in calendar years. It also allows us to link the age of an object such as pottery with its archaeological context. Directly, the researches may correlate the time when the pottery was formed with the time and place of use (Feathers, 2003; Preusser et al., 2008). These advantages led to the situation that the TL method has been repeatedly used in archaeological studies (e.g. Fleming, 1979). After 1980 its importance has declined significantly since it became possible to receive calibration of ${ }^{14} \mathrm{C}$ dates, which means transformation of radiocarbon age into the calendar years (Preusser et al.,

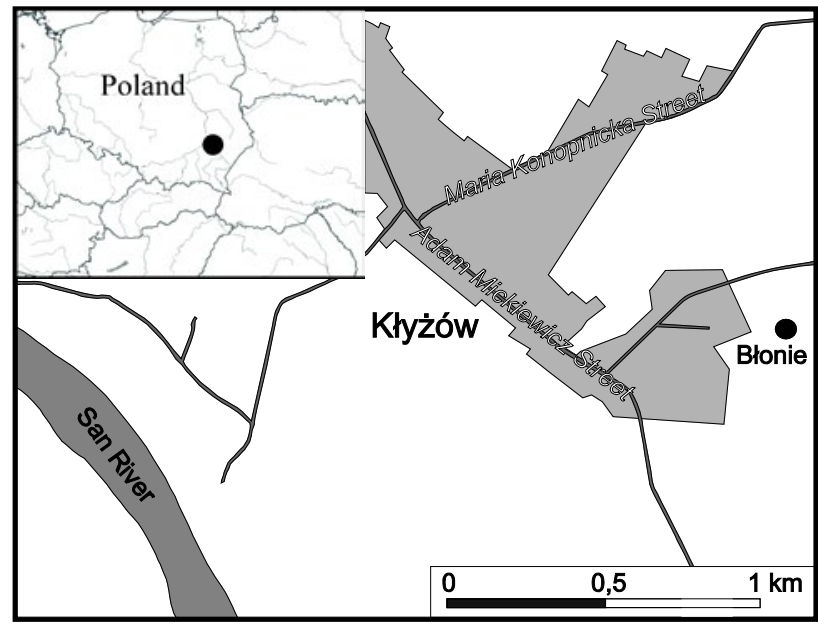

Fig. 1. Kłyżów, dist. Stalowa Wola, site 2. Location of the site.

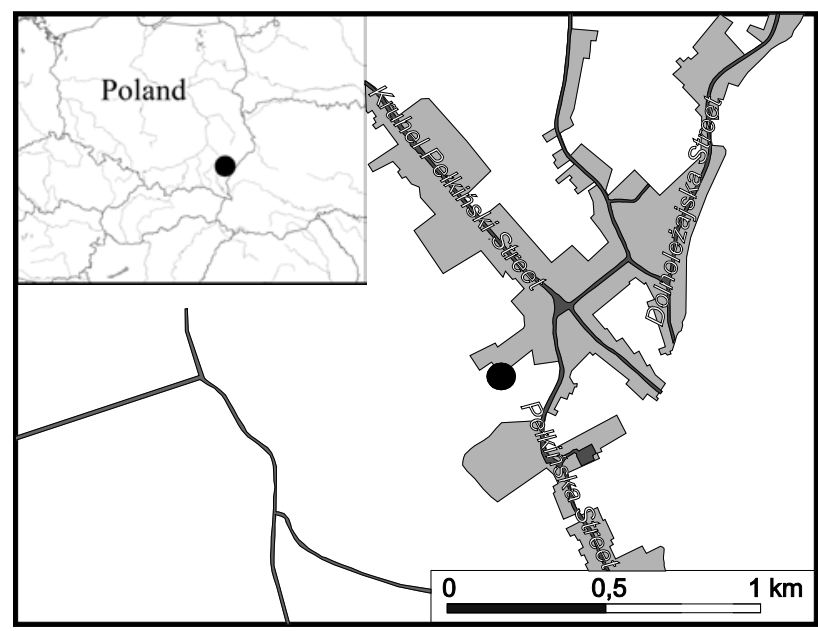

Fig. 2. Jarosław, dist. loco, site 158. Location of the site.

2008). Despite this, the dating of burnt materials were and still are determined in many laboratories (e.g. Benea et al., 2007; Blain et al., 2011; Chruścińska et al., 2008; Preusser et al., 2008; Sánchez et al., 2008; Wintle, 2008). It is reasonable to present a list a few applications of the TL method that deserve special attention. Based on the dates obtained from about 170 samples of pottery from the Late Bronze and Iron Age from the territory of the UK, Barnett $(1999,2000)$ presented the possibility of using large sets of TL dates to verify and clarify the chronology based on stylistic, technological and raw materials dating. Feathers (2003) presented 500 results of TL dating samples of pottery carried out in a laboratory at the University of Washington. Bailiff (2007) described the achievements in the field of dating bricks and practical application of these results. Zink and Porto (2005) investigated a large collection of Tanagra figurines and used a probability statistic to distinguish fake from authentic ones. 
In Poland, the history of TL dating is much shorter. The first thermoluminescence laboratory was established in the mid-1970s of the twentieth century at the University of Warsaw. Routine luminescence dating of mineral sediments has been made since the beginning of the 1980 s in several laboratories. Comparing to the frequency of use of this method in studies of Pleistocene sediments, the method of TL dating of pottery, has been carried out quite rarely. At the end of the 20th century it was conducted primarily in the Department of Radioisotopes, at the Silesian University of Technology. A detailed description of dating methodology was presented by Bluszcz (1989). The results containing a summary of several research projects were published by Bluszcz and Adamiec (1994), Bluszcz and Pazdur (1994a, 1994b). They presented about 80 dates from the Neolithic to the Early Middle Ages. After about a ten-year break researchers started again dating pottery, but in a different research centre, in the laboratory of thermoluminescence in the Department of Physical Geography and Paleogeography at MCSU in Lublin (now the Department of Geoecology and Paleogeography). In 2005, the researchers inspired by Buko (Institute of Archaeology and Ethnology PAN) attempted to date four samples of pottery from the Early Medieval sites in Busówno, Czułczyce and Horodysko located near Chełm (Lublin voivodeship). At the same time, Lublin TL laboratory established an informal cooperation with the Institute of Archaeology at the University of Łódź. First results were presented at the conference "Current problems of the Stone Age in Pomerania" in Gdańsk on 25-27 October, 2006 (Kusiak et al., 2009). For several years the laboratory from Lublin has taken further attempts at pottery dating from several sites from the area of Poland and Ukraine, ranging from the Trypillian culture to the Middle Ages. The most interesting were the studies on the dating of early Early Medieval strongholds in Busówno (Lublin voivodeship) and Nowiniec (Lubusz voivodeship) and settlements Nieszawa Kolonia (Lublin voivodeship) and Rawa Mazowiecka (Łódź Voivodeship) from the Roman Period (Buko et al., 2008; Kusiak, 2011; Kusiak et al., 2011).

\section{DESCRIPTION OF DATING METHOD}

The TL age is a quotient of archaeological dose (AD) and dose rate (DR). The archaeological dose is a sum of the equivalent dose (ED) and correction (I) due to the fact of non-linear increase of thermoluminescence for small absorbed doses (Mejdahl and Wintle, 1984).

The dose rate is calculated from the measured concentrations of natural radioisotopes in a sample of pottery and sample of deposit in which it was found. The concentrations of radioisotopes obtained in $\mathrm{Bq} / \mathrm{kg}$ are converted into absorbed dose rates for $\alpha, \beta$ and $\gamma$ radiation in Gy/ka, based on the data published by Adamiec and Aitken (1998) and Olley et al. (1996). In the calculation of dose rate, the correction $\left(D_{\text {cosm. }}=0.19 \mathrm{~Gy} / \mathrm{ka}\right)$ for cosmic ra- diation (Prescott and Hutton, 1994) and the correction $\mathrm{k}=0.1$ (for small effectiveness of generating thermoluminescence when subjected to $\alpha$ radiation) are made (cf. Benea et al., 2007). The dose rate (DR) was calculated as a sum of components coming from $\alpha$ and $\beta$ radiation emitted by nuclides occurring in the pottery sample and absorbed by mineral grains of this sample, $\gamma$ radiation emitted by isotopes occurring in deposit but absorbed by mineral grains of pottery sample (Bluszcz and Adamiec, 1994). A Canberra high-resolution gamma spectrometer with a high purity HPGe type $\mathrm{P}$ and of $30 \%$ efficiency detector was used to determine the content of $\mathrm{K}$, U, Th. The measurements of radioisotopes were carried out with the application of two various geometries: for the deposit portions of about $0.6 \mathrm{dm}^{3}$ in volume in Marinelli-type containers, for the pottery - plates (not crushed) of $60-100 \mathrm{~g}$ in weight and about $60 \mathrm{~mm}$ in diameter. The measurement time was 86 ks (Poręba and Fedorowicz, 2005). Portions of mineral material weighing about $100 \mathrm{~g}$ are used in other laboratories for example in The Nordic Centre for Luminescence Research. Similar approach is mentioned by Preusser et al. (2008). The method of determining the annual dose for pottery plates was chosen because of the possibility of obtaining valuable artifacts for analysis. Set of radioactive standards with a capacity of $50 \mathrm{~cm}^{3}$ was used as calibration standards. In measurements pieces of ceramics of the same diameter as the calibration standards were used, but of different thickness. For this reason, normalization of counts from samples was made in order to relate the volume of sample with a capacity of standards. The dose rate was calculated with the correction for sediment moisture of about $18 \%$ for Jarosław site (loess) and 10\% for Kłyżów site (sand) and samples moisture of about $10 \%$ for Jarosław site and $5 \%$ for Kłyżów site which was determined based on the measurement of natural humidity and moisture of saturation. All sample preparation was carried out under red light conditions with use Kaiser spectral 590 lamp. In order to determine the archaeological dose a pottery sample of about $10 \mathrm{~g}$ in weight was taken and its 1-2 mm thick external layer was removed. Then a sample was carefully crushed and the $30-40 \mu \mathrm{m}$ polymineral fraction was separated by sieving. The obtained mineral material was cleaned by etching with $\mathrm{HCl}$ and $\mathrm{H}_{2} \mathrm{O}_{2}$. Separation of minerals was not made. The mineral material was divided into two parts. The first one was divided into several portions. One was left in natural form, and the remaining portions were irradiated with the ionising radiation doses of $10 \mathrm{~Gy}, 20 \mathrm{~Gy}, 30 \mathrm{~Gy}$ and $40 \mathrm{~Gy}$. Then the mineral material was divided into portions of $4 \mathrm{mg}$ in weight (24 portions for a single dose), which were placed in the TL reader/analyser RA'94 type (with the EMI 9789 QA photomultiplier) produced by Mikrolab Kraków (Poland). Aliquots were glowed out in argon atmosphere at a heating rate of $10^{\circ} \mathrm{C} / \mathrm{s}$ up $400^{\circ} \mathrm{C}$. The equivalent dose (ED) was determined by multiple-aliquot additive method. In order to determine the correction (I) due to the fact of 
non-linearity of the relationship TL $=\mathrm{f}(\mathrm{D})$ (where $\mathrm{TL}-$ thermoluminescence, $\mathrm{D}$ - dose of radiation) for small absorbed doses, the second part of mineral material was heated at $500^{\circ} \mathrm{C}$ for 6 hours (Polymeris et al., 2007; Roque et al., 2004). Then it was divided into portions and irradiated with the same doses as those used for ED determination. The correction (I) was determined by multiple-aliquot regeneration method. During thermoluminescence measurements an optical filter HA-3 was used to cut infrared radiation of heater. The TL light sum was read under narrow region range $10^{\circ} \mathrm{C}$ of the $\mathrm{TL}$ glow curve around its maximum. The samples have been preheated for 3 days at $80^{\circ} \mathrm{C}$ prior to the read-out. Method A from Huntley and Lamothe (2001), where aliquots are irradiated at different times and measured all at the same time was used to measure the loss of luminescence per decade of time ( $g$ value). The confidence interval of the obtained values of TL age was adopted at the $68 \%$. The values of dose rate (DR), archaeological dose (AD) and $\mathrm{TL}$ age are listed in Tables $\mathbf{1}$ and $\mathbf{2}$.

\section{KŁYŻÓW, SITE 2}

The cemetery at site 2 in Kłyżów, dist. Stalowa Wola was explored by Szarek-Waszkowska in 1974, in form of typical rescue excavations (the cemetery was located within the sand dune, where building material was intensively taken out for building the railway embankment between Nisko and Biłgoraj). This site has not been yet the subject of a separate study, but it is known from various references or articles (see Szarek-Waszkowska, 1975a, 1975b; Czopek, 1992, 1996; Trybała-Zawiślak, 2005).

During the excavation, 209 graves were discovered (the number after verification), which were arranged in a distinctive, elongated or approximately oval clusters, usually numbering several graves, situated along the eastwest axis (Fig. 3). Cemetery dating ranges in a relatively narrow time frame. This reflects the typological density of artefacts, which causes many difficulties, both in terms of designation of the chronological framework of the cemetery, as well as in attempting to make the periodiza-

Table 1. The results of thermoluminescence dating of pottery samples from site No. 2 in Kłyżów.

\begin{tabular}{|c|c|c|c|c|c|c|c|c|c|}
\hline $\begin{array}{c}\text { Gravel } \\
\text { Sample No. } \\
\text { Lub- }\end{array}$ & $\begin{array}{c}\mathrm{K} \\
(\mathrm{Bq} / \mathrm{kg})\end{array}$ & $\underset{(B q / k g)}{U}$ & $\begin{array}{c}\text { Th } \\
\text { (Bq/kg) }\end{array}$ & $\begin{array}{c}\text { Dose rate DR } \\
\text { (Gy/ka) }\end{array}$ & $\begin{array}{c}\text { Plateau test/ } \\
\text { MAX of glow curve } \\
\left({ }^{\circ} \mathrm{C}\right)\end{array}$ & $\begin{array}{c}\text { I } \\
\text { (Gy) }\end{array}$ & $\begin{array}{c}g \\
\text { value } \\
(\% / d e c .) \\
\end{array}$ & $\begin{array}{c}\text { Archaeo-logical } \\
\text { dose } A D \\
(G y) \\
\end{array}$ & $\begin{array}{c}\text { TL age } \\
\text { (yrs) } \\
\text { [before 2010] }\end{array}$ \\
\hline $60 / 4850$ & $624 \pm 22$ & $42,1 \pm 2.1$ & $51.2 \pm 2.1$ & $3.79 \pm 0.17$ & $277-436 / 299$ & 1.1 & 1.6 & $10.55 \pm 0.53$ & $2770 \pm 186$ \\
\hline $61 / 4851$ & $671 \pm 25$ & $47.3 \pm 2.2$ & $46.2 \pm 1.9$ & $3.91 \pm 0.14$ & $272-418 / 280$ & 0.8 & 0 & $11.00 \pm 0.55$ & $2813 \pm 172$ \\
\hline $62 / 4852$ & $841 \pm 29$ & $69.3 \pm 2.9$ & $77.1 \pm 2.8$ & $5.59 \pm 0.26$ & $261-418 / 281$ & 1.0 & 0.7 & $15.40 \pm 0.77$ & $2755 \pm 187$ \\
\hline $63 / 4853$ & $752 \pm 26$ & $52.1 \pm 2.3$ & $46.6 \pm 1.7$ & $4.27 \pm 0.21$ & $270-427 / 280$ & 0.9 & 1.3 & $11.50 \pm 0.58$ & $2693 \pm 189$ \\
\hline $64 / 4854$ & $726 \pm 23$ & $48.2 \pm 2.2$ & $46.1 \pm 1.8$ & $4.16 \pm 0.20$ & $275-432 / 280$ & 0 & 0 & $8.50 \pm 0.41$ & $2043 \pm 143$ \\
\hline $65 / 4855$ & $697 \pm 24$ & $57.1 \pm 2.7$ & $55.2 \pm 2.2$ & $4.39 \pm 0.21$ & $260-391 / 275$ & 1.2 & 0.6 & $11.80 \pm 0.59$ & $2688 \pm 161$ \\
\hline $123 / 4856$ & $622 \pm 22$ & $47.1 \pm 2.1$ & $47.2 \pm 2.0$ & $3.91 \pm 0.19$ & $247-448 / 270$ & 1.1 & 0 & $9.90 \pm 0.50$ & $2532 \pm 177$ \\
\hline $124 / 4857$ & $872 \pm 31$ & $89.1 \pm 3.7$ & $82.1 \pm 2.9$ & $6.02 \pm 0.30$ & $265-436 / 285$ & 0.5 & 2.0 & $15.70 \pm 0.79$ & $2608 \pm 185$ \\
\hline $125 / 4858$ & $144 \pm 5$ & $24.1 \pm 1.1$ & $29.2 \pm 1.1$ & $1.95 \pm 0.11$ & $272-390 / 285$ & 0.7 & 1.5 & $14.50 \pm 0.73$ & $7436 \pm 565$ \\
\hline $126 / 4859$ & $567 \pm 20$ & $49.8 \pm 2.3$ & $44.1 \pm 2.1$ & $3.84 \pm 0.17$ & $277-428 / 285$ & 0 & 0 & $9.50 \pm 0.48$ & $2474 \pm 166$ \\
\hline sand & $69 \pm 4$ & $3.2 \pm 0.3$ & $3.1 \pm 0.2$ & $0.10 \pm 0.01^{*}$ & & & & & \\
\hline
\end{tabular}

* only the element of gamma radiation

Table 2. The results of thermoluminescence dating of pottery samples from site No. 158 in Jarosław.

\begin{tabular}{|c|c|c|c|c|c|c|c|c|c|}
\hline $\begin{array}{c}\text { Featurel } \\
\text { Sample No. } \\
\text { Lub- }\end{array}$ & $\begin{array}{c}\mathrm{K} \\
(\mathrm{Bq} / \mathrm{kg})\end{array}$ & $\underset{(B q / k g)}{U}$ & $\begin{array}{c}\text { Th } \\
(\mathrm{Bq} / \mathrm{kg})\end{array}$ & $\begin{array}{l}\text { Dose rate DR } \\
\text { (Gy/ka) }\end{array}$ & $\begin{array}{c}\text { Plateau test } / \\
\operatorname{MAX} \text { of glow curve } \\
\left({ }^{\circ} \mathrm{C}\right)\end{array}$ & $\begin{array}{c}\text { I } \\
\text { (Gy) }\end{array}$ & $\begin{array}{c}g \\
\text { value } \\
(\% / \text { dec.) }\end{array}$ & $\begin{array}{c}\text { Archaeo-logical } \\
\text { dose AD } \\
\text { (Gy) }\end{array}$ & $\begin{array}{c}\text { TL age } \\
\text { (yrs) } \\
\text { [before 2010] }\end{array}$ \\
\hline $5 / 4839$ & $697 \pm 24$ & $43.4 \pm 2.0$ & $49.3 \pm 1.9$ & $4.95 \pm 0.25$ & $286-430 / 290$ & 1.1 & 1.6 & $11.64 \pm 0.58$ & $2352 \pm 166$ \\
\hline $22 / 4840$ & $514 \pm 19$ & $44.4 \pm 2.0$ & $47.7 \pm 1.9$ & $4.48 \pm 0.22$ & $225-335 / 280$ & 0.8 & 0 & $10.82 \pm 0.54$ & $2416 \pm 169$ \\
\hline $58 / 4841$ & $669 \pm 25$ & $48.2 \pm 2.2$ & $49.7 \pm 2.1$ & $5.00 \pm 0.25$ & $277-355 / 285$ & 1.0 & 0.7 & $13.42 \pm 0.67$ & $2684 \pm 188$ \\
\hline $191 / 4842$ & $708 \pm 24$ & $64.3 \pm 2.8$ & $51.8 \pm 2.0$ & $5.49 \pm 0.27$ & $265-396 / 282$ & 0.9 & 1.3 & $15.40 \pm 0.77$ & $2805 \pm 196$ \\
\hline $237 / 4843$ & $660 \pm 24$ & $44.5 \pm 2.1$ & $50.8 \pm 2.0$ & $4.91 \pm 0.25$ & $270-410 / 282$ & 0.5 & 1.2 & $14.00 \pm 0.70$ & $2851 \pm 200$ \\
\hline $354 / 4844$ & $822 \pm 25$ & $52.9 \pm 2.3$ & $60.2 \pm 2.2$ & $5.61 \pm 0.28$ & $260-410 / 286$ & 1.2 & 2.0 & $15.44 \pm 0.77$ & $2752 \pm 193$ \\
\hline $386 / 4845$ & $734 \pm 29$ & $55.0 \pm 2.5$ & $61.3 \pm 2.3$ & $5.41 \pm 0.27$ & $270-410 / 291$ & 1.1 & 0.6 & $15.32 \pm 0.77$ & $2832 \pm 198$ \\
\hline $495(1) / 4846$ & $708 \pm 25$ & $44.2 \pm 2.1$ & $45.3 \pm 1.9$ & $4.92 \pm 0.25$ & $283-390 / 288$ & 0.5 & 0 & $11.24 \pm 0.56$ & $2285 \pm 160$ \\
\hline $495(2) / 4847$ & $582 \pm 21$ & $51.6 \pm 2.4$ & $47.3 \pm 2.0$ & $4.82 \pm 0.24$ & $274-427 / 288$ & 0.7 & 0 & $11.54 \pm 0.58$ & $2394 \pm 168$ \\
\hline 12524848 & $734 \pm 28$ & $46.6 \pm 2.3$ & $52.7 \pm 2.0$ & $5.21 \pm 0.26$ & $274-440 / 285$ & 0.9 & 1.3 & $12.60 \pm 0.63$ & $2418 \pm 169$ \\
\hline \multirow[t]{2}{*}{$1255 / 4849$} & $708 \pm 25$ & $48.8 \pm 2.4$ & $56.9 \pm 2.0$ & $5.24 \pm 0.26$ & $247-430 / 290$ & 0.5 & 0.5 & $11.08 \pm 0.55$ & $2115 \pm 148$ \\
\hline & $582 \pm 18$ & $27.3 \pm 0.6$ & $46.1 \pm 1.3$ & $1.04 \pm 0.03^{*}$ & loess & & & & \\
\hline
\end{tabular}

* only the element of gamma radiation 


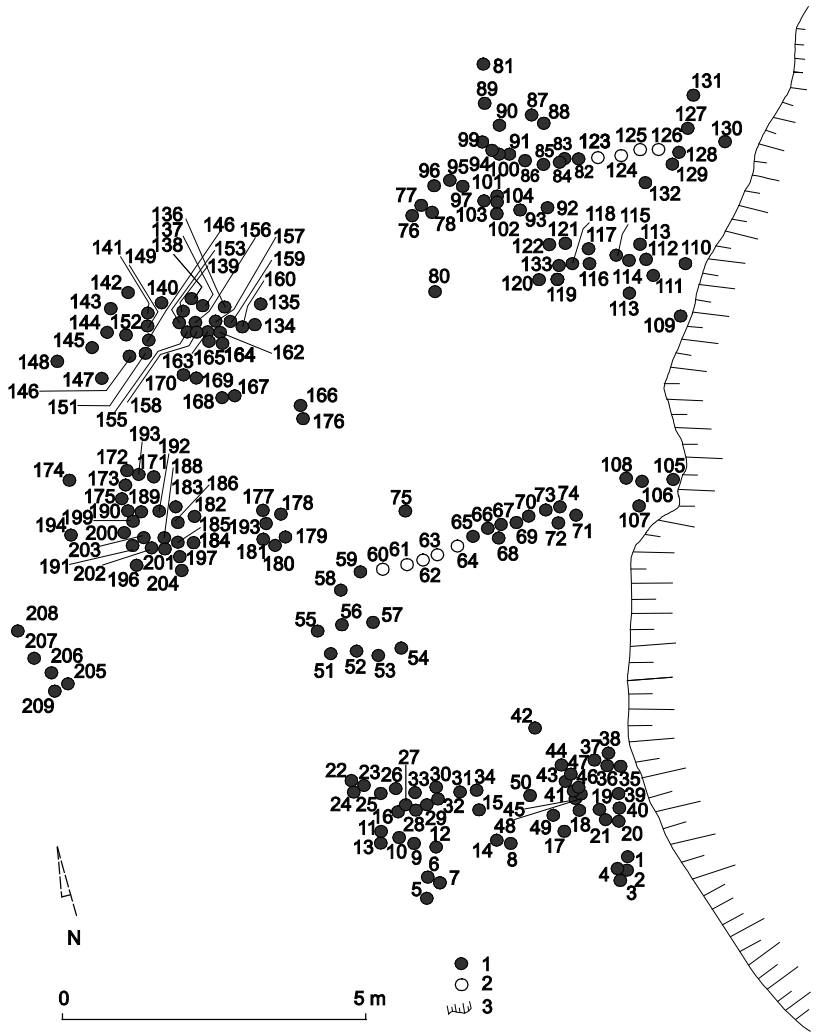

Fig. 3. Kłyżów, dist. Stalowa Wola, site 2. Plan of the cemetery within the designation of the graves indication for which the $T L$ analysis was performed (1. urn graves; 2. graves with TL analysis; 3. destroyed area).

tion of archaeological evidence. According to the latest findings, the beginning of the necropolis in Kłyżów should be designated to Hallstatt D1 (= HaD1), and its decline within $\mathrm{HaD} 2-\mathrm{HaD} 3$ period. Recent findings made us place the beginning of $\mathrm{HaD}$ more or less in half of the seventh century BC (Czopek 2001; Czopek and Poradyło 2008). At the same time, the researchers drew attention to the fact that in comparison with recent studies in the field of chronology and periodization, dating of the Early Iron Age of Polish territories is still insufficiently developed, but it could be assumed that the older part of the declining phase of the Tarnobrzeg Lusatian culture, i.e. phase $\mathrm{III} / 1$, in whole corresponds to the period $\mathrm{HaD}$ and it falls to the end of the seventh and sixth centuries $\mathrm{BC}$, whereas the phase III/2 would match with the La Téne (further: Lt) A period (or in other terminology, "HaE") and partly $\mathrm{LtB}$, which corresponds to the fifth and fourth centuries BC (Czopek 2007). This concept is consistent with recent findings of Trachsel, who dates the period $\mathrm{HaC}$ restricted to $800-660 \mathrm{BC}, \mathrm{HaD}$ to $650-530 / 510 \mathrm{BC}$, while the period of old La Tenè $(=\mathrm{LtA})$ was placed between 520 and $420 \mathrm{BC}$, where each of them has been divided into narrower (early, middle and late) time segments (Trachsel, 2004). The last period would correspond to the decline of the Tarnobrzeg Lusatian culture.
During the exploration of the necropolis in Kłyżów were found a number of eastern and south-eastern analogies in ceramic and metal artifacts. There was encountered an arrangement of graves, which was not registered within the cemeteries about earlier chronology. These new findings gave rise to questions about the period of use of the various parts of the cemetery and the reason for the creation of rows or clusters in arrangement of buriels. It should be emphasised that the chronology and periodization of archaeological evidence are of great importance, because they are a starting point for any analytical and synthetic discussion. Both, the typological dating and the limited capability of stratigraphic systems, do not provide a clear and complete answer to the question concerning the periodization of source materials from the cemetery in Kłyżów. In this situation, absolute dating should be used to obtain such data. Two attempts have been made to carry out such an analysis for selected inventories.

The first study was ${ }^{14} \mathrm{C}$ dating conducted on burnt bone fragments. Unfortunately, this analysis delivered negative results, because the bones were completely devoid of collagen as a result of washing out which occurred during the movement of water in the soil ${ }^{1}$. Therefore, an attempt was made to date sherds of pottery by means of the TL method. As the result of the analysis, it was possible to establish reliable dates for 8 out of 10 examined graves (Table 1). One of them (grave 64) yielded an underestimated date, while the second one (grave 125) yielded a significantly overestimated date.

The pottery for TL dating came from the graves located in two clusters which were the most noticeable for their linear (row) arrangement. The first cluster was the source of 6 selected samples (graves 60-65), the second one -4 samples (graves 123-126).

Essential and fundamental issue in this case is the composition of the funerary inventory.

Grave 60 - it contained a nadsańska vase in a postclassical form (Fig. 5: 1), decorated by plastic knobs in the place of transition of the belly into the neck and groups of knobs ( 3 in each) on the shoulder. The vessel was devoid of any incised decoration characteristic for the classical nadsańska style. In addition, there was a small bronze object in the inventory in the form of ringspiral with overlapping endings (Fig. 5: 3). The data obtained $^{2}$ for the grave was $2770 \pm 186$ years [before 2010] [946-574 BC].

Grave 61 - it contained a slim vase type vessel with an ill-defined biconical body and a slim conical neck, decorated by a horizontal incised line at transition from the belly to the neck, and pairs of plastic knobs and

\footnotetext{
${ }^{1}$ According to oral information obtained from prof. dr hab. Marek Krapiec on the base of conducted analysis.

${ }^{2}$ On the grounds of conducted research it can be assumed that in the Tarnobrzeg Lusatian Culture grave pottery was created on the purpose of the burial. Therefore, TL dating (establishing when a vessel was bleached) may also be valid for the grave.
} 
groups of incised slashes below (Fig. 4: 9). The data obtained from this sample was $2813 \pm 172$ years [before 2010] [975-631 BC].

Grave 62 - it is a single element set in the form of a vase type vessel with a round belly and an ill-defined shoulder and the neck, which is in a conical shape in preserved part. The shoulder is decorated by incised ornamentation in the form of groups of slashes separated by small notches (Fig. 4: 1). The vessel represents a typical Lusatian form and therefore it can be regarded as a typical production of the Tarnobrzeg Lusatian culture. The data obtained for this grave was $2755 \pm 187$ years [before 2010] [932-558 BC].

Grave 63 - it contained a vase type vessel. It is a form of slightly profiled body with a gently rounded belly and cylindrical neck. An incised decoration is crucial in this case because of the similarity to the ceramics of the late Chernoles culture, in the form of multiple, carelessly made zigzags and slashes, which in several places are arranged in the shape of crosses and possibly stars . Additionally, the belly was also decorated by plastic knobs (Fig. 4: 7). The data obtained for the vessel oscillates in the range of $2693 \pm 189$ years [before 2010] [872-494 $\mathrm{BC}$.

Grave 64 - it was a set of biconical vessel (Fig. 4: 2-
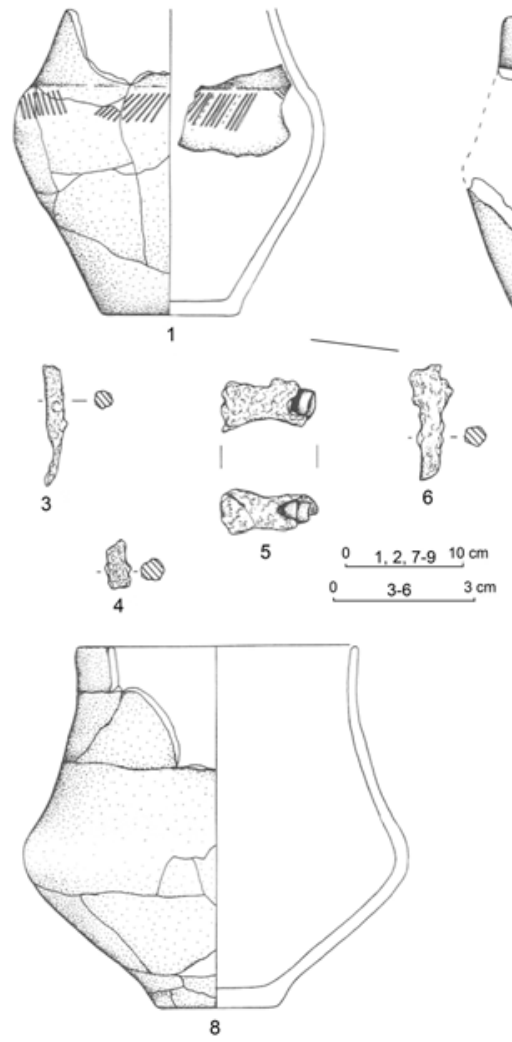

Fig. 4. Kłyżów, dist. Stalowa Wola, site 2. Grave inventories (61: 9; 62: 1; 63: 7; 64: 2-6; 65: 8).

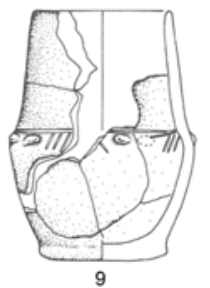

6), and fragments of melted iron artefacts and a bronze bead salta leone. The data obtained for the grave is clearly rejuvenated (2 043 \pm 143 years [before 2010] [176 BC$110 \mathrm{AD}])$, so it cannot be used in analytical considerations.

Grave 65 - it was furnished only with a vase type vessel of a rounded belly and a conical neck and a slightly conical rim flaring outside (Fig. 4: 8), which represents one of the distinctive features of the Tarnobrzeg Lusatian culture in its declining phase of the pottery types. The grave was dated between $2688 \pm 161$ years [before 2010] [839-517 BC].

Grave 123 - it was furnished with a vase type vessel of a biconical belly and relatively short flaring neck. There was a hole, not fully punctured below the edge of the rim (Fig. 5: 2). The data obtained in the analysis oscillates around $2532 \pm 177$ years [before 2010] [699$345 \mathrm{BC}]$.

Grave 124 - it was a set of a vase type vessel with a rounded and well-defined shoulder and a conical neck (preserved in fragments). The vessel was decorated by a single horizontal incised line at transition from the belly to the neck, and groups of incised slashes below (Fig. 5: 4). Both in terms of form and ornamentation, this vessel represents a typical Lusatian ceramic form, which may be
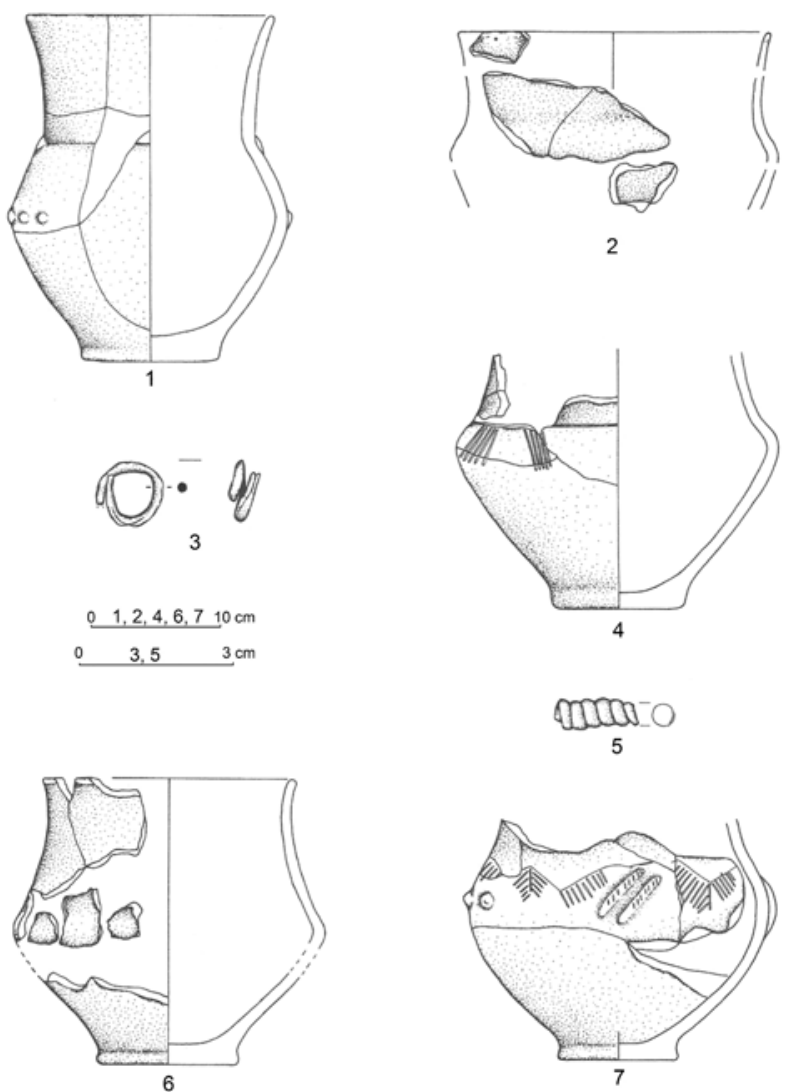

Fig. 5. Kłyżów, dist. Stalowa Wola, site 2. Grave inventories (60: 1, 2; 123: 3; 124: 4, 5; 125: 6; 126: 7). 
considered also in the Tarnobrzeg Lusatian culture as one of the leading types in materials related to its late phase. Additionally, there was a bronze bead salta leone (Fig. 5: 5). The data obtained for this inventory is $2608 \pm 185$ years [before 2010] [783-413 BC].

Grave 125 - it contained a vessel with biconical belly smoothly passing into the conical neck of flaring rim (Fig. 5: 6). The vessel could be considered as one of the fairly common in the Tarnobrzeg Lusatian culture forms, dated to the late second and third phase of development. Unfortunately, the date obtained for the pottery coming from the grave was much inflated $7436 \pm 565$ years [before 2010] [5 991-4 861BC].

Grave 126 - it contained another example of the pottery form, which clearly indicates foreign, eastern influences. A vase (which unfortunately has not been preserved in its entirety) is characterized by a very interesting and complex ornamentation which consists of herringbones and slashes as well as plastic knobs arranged in pairs and strips, which are also decorated in small, notched slashes (Fig. 5: 7). These motifs are very popular, almost leading, in ceramics of the Vysocko culture. TL dating of this grave is in the range $2474 \pm 166$ years [before 2010] [630-298 BC].

Thus, taking into account the dates obtained for each piece of inventories, it is possible to conclude that the oldest analysed grave could be grave 61 , dated to the end of $9^{\text {th }}$, or at the turn of $9^{\text {th }}$ and $8^{\text {th }}$ century BC $(803 \pm 172$ $\mathrm{BC})$. Slightly younger are the graves 60 and 62 , which chronology is established to half of $8^{\text {th }}$ century BC (data $760 \pm 186 \mathrm{BC}$ and $745 \pm 187 \mathrm{BC}$ ), then graves 63 and 65 with dates falling into the first half of $7^{\text {th }}$ century $\mathrm{BC}$ (dates $683 \pm 189 \mathrm{BC}$ and $678 \pm 161 \mathrm{BC}$ ). The graves from the next isolated clusters $(123,124$ and 126) seem to be a bit younger, i.e.: the date for grave 124 falls into the beginning of the $6^{\text {th }}$ century BC $(598 \pm 185 \mathrm{BC})$, while for the grave 123 at the end of $6^{\text {th }}$ century BC $(522 \pm 177 \mathrm{BC})$. The youngest analysed burial could be grave 126 dated to about half of $5^{\text {th }}$ century BC (date $464 \pm 166$ BC) (Fig. 6).

The obtained dates are in the range from $2813 \pm 172$ years [before 2010] to $2474 \pm 166$ years [before 2010], but considering the example it is not possible to demonstrate the temporal sequence of individual burials. Observing the chronological range established for some graves we may only notice their "overlapping" and fairly large density in time. Only in one case, we are able to speak of an almost direct sequence in time of the burials. This situation applies to grave 61 , for which the interval falls into years $975-631 \mathrm{BC}$ and grave 126 dated to years 630-298 BC.

Let us have another look at typological dating, this time taking into account conclusions based on the absolute chronology. As it was previously stated, it seems that the cemetery was founded in Kłyżów during the period corresponding to the decline Phase II of the Tarnobrzeg Lusatian culture development, which may be proved by the presence of pottery made in the post-classical nad- sańska style (nadsańska vases, zbydniowska bowl). The date obtained for grave 60 (which contained a vessel having a form of nadsańska vase, but with a very poor ornamentation restricted only to the plastic decoration) is not only one of the earliest among the analysed samples, but it also perfectly fits into the chronological range corresponding to the decline of the middle development phase of the Tarnobrzeg Lusatian culture, which falls more or less into the end of $7^{\text {th }}$ - the beginning of the $6^{\text {th }}$ century BC (Czopek 2001). The group of the oldest inventories could also include those with the vases of sharp ridges at the body and flaring necks, named by Przybyła (2003) type 20, which chronology falls into the younger part of Phase II. Similar situation developed in case of profiled bowls, which accompanied in Kłyżów necropolis the vases distinctive for Phase III of the Tarnobrzeg Lusatian culture. The results of analysis of TL dating conducted on the samples coming from such vessels also do not contradict the chronology, which according to current study should fall into the younger part of the late phase, i.e. the period corresponding to the $6^{\text {th }}-5^{\text {th }}$ century BC (Czopek 2007; Czopek and Poradyło 2008). It is a striking fact that in case of the cemetery in Kłyżow, basically we do not have the ceramic materials that could be definitely attributed to the youngest horizon of the Tarnobrzeg Lusatian culture (phases III2, see Czopek 2007). In this case it is necessary to evoke the results of TL dating. On the one hand, boundary dates (final) of three samples fall into the end of $5^{\text {th }}$, half of $4^{\text {th }}$, and even the beginning of the $3^{\text {rd }}$ century BC (graves 124,123 and 126), which would mean the possibility of their inclusion in phase III2 (see Czopek 2001, 2007). On the other hand, the chronological range, in which the discussed inventories can be placed, lets us affiliate them even with the older part of the late phase of the Tarnobrzeg Lusatian culture. It seems that the lack of coarse pots on the one

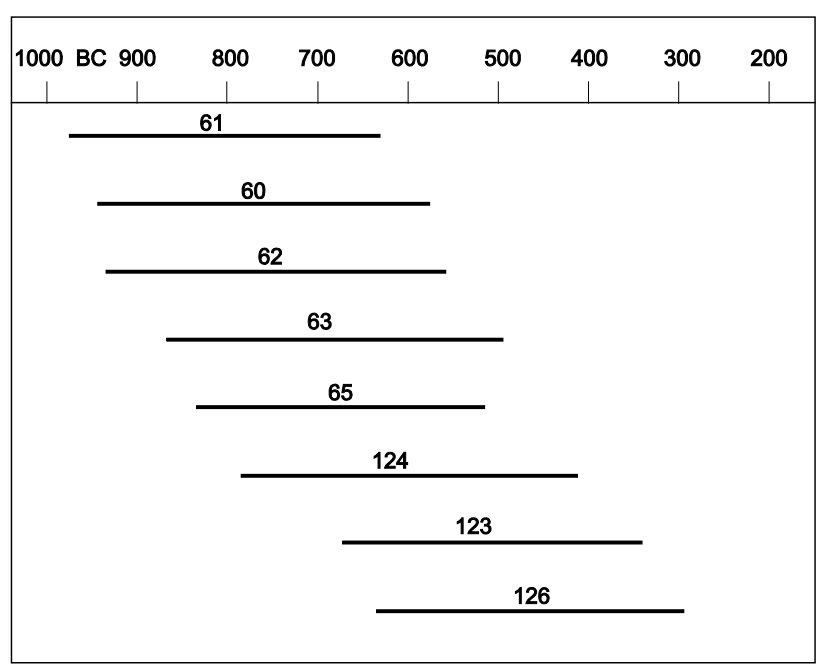

Fig. 6. Kłyżów, dist. Stalowa Wola. The results of TL dating (with $68 \%$ probability range). 
hand and the presence of the characteristic metal artefacts such as nail-shaped earrings, or earrings of Kłyżów type within vase type vessels on the other hand, finally let us confirm that the cemetery in Kłyżow did not function any longer at the time corresponding to the youngest horizon of the Tarnobrzeg Lusatian culture.

The earrings discovered at the cemetery in Kłyżów represent several types dating of which falls primarily into the 2 nd half or the end of the $7^{\text {th }}$ and $6^{\text {th }}$ centuries BC. Two elements (unfortunately of uncertain location, coming from the so-called isolated finds) are affiliated with slightly later chronology, ranging roughly from the end of $6^{\text {th }}$ to $4^{\text {th }}$ century BC.

Among the samples destined for dating by means of thermoluminescence, there were also those coming from the vessels of "eastern" connections (graves: 63 - ornamentation made in the late Chernoles type, 123 - not quite pierced holes under the rim, 126 - herringbone ornaments, found in the Vysocko type ceramics). Point dates obtained for these inventories fall respectively into: 1 half of $7^{\text {th }}$ century BC, the end of $6^{\text {th }}$ century BC and half of $5^{\text {th }}$ century $\mathrm{BC}$, however the time span in which they are located does not negate the inclusion of all inventories within the range from $7^{\text {th }}-5^{\text {th }}$ century BC.

Moreover, it is extremely difficult to assign the final phase of the cemetery. While the pottery in nadsańska style, profiled bowl or strongly-profiled vases are typical for the initial phase, the final phase is difficult to characterize. Taking into account the chronological framework of the whole evidence, it is possible that a part of the vessels with eastern analogies are of slightly later date. Accordingly, these may be associated with the final phase of the cemetery. The final phase may represent also assemblages containing iron artefacts as well as nail-shaped earrings, and perhaps also the burials with pot-shaped vessels.

Grave inventories coming from the cemetery in Kłyżów are undoubtedly a very interesting set of archaeological evidence - thanks to the influences of numerous eastern elements which affected the Tarnobrzeg environment, even though they were extraneous there. It is not only indicated by pottery, but also the nail-shaped earrings may confirm the relationship with the forest steppe zone of Ukraine, which seems to be indisputable (Czopek 2007). Apart from the cemetery in Kosina, the discussed necropolis in Kłyżów is the next one, which confirms so many infiltrations from the outside territory. Therefore, it is so important to survey the issue considering the location of these inventories in time, within the attempts to identify the chronological stratification of individual burials in general.

The dates obtained by TL method not only allow us to place the inventories at the right time frame, but they also enable (even though with extreme caution) to indicate some time relationships between both the Lusatian (Tarnobrzeg) complex and the 'outside' complex (e.g. graves 63 and 60 may come from almost the same time, but graves 61 and 126 may illustrate a direct sequence in time) as well as certain relationships within the last ones (e.g. grave 63 may be a bit earlier than grave 126).

The TL analysis of the pottery from graves 64 and 125 has demonstrated that it is possible to obtain TL dates clearly differing from the expected age. Bluszcz and Pazdur (1994b) suggested that the reasons for such differences might come from wrong methods of archaeological dating of artefacts or features. Preusser et al. (2008) also drew attention to this problem. They found that when using TL dating of clay products, special attention should be paid to the term "lifetime" of the artefact. There are features such as ovens, whose life could be very long. TL method can determine only the time which has elapsed since the last use, and not since the time of construction. In case of pottery, it is possible to obtain dates both older and younger from the time of functioning of the human habitat from which the samples were collected for dating. It may result from the displacement of artefacts. Changing the place of deposited ceramics could result from different factors. In case of violent climatic events leading to soil transport, artefacts may be transported together with sediment layer in which they are buried. Also the possibility of conducting earthworks should be taken into account. During the time of features constructions, younger fragments of pottery could get into the trenches, while the older ones might have been moved to the newly created embankments. However, in case of graves 64 and 125 , it seems that none of the above cases applies. Moreover, other causes were eliminated, i.e. for the sample coming from grave 64, there were no evidences of anomalous fading and supralinearity of thermoluminescence growth curve. On the basis of dates obtained for about 500 clay vessels Feathers (2003) claimed that about 85\% of the results received in the laboratory at Washington University correlate well with the expected age, defined on the basis of independent methods of dating. It can therefore be assumed that there is a group of dates not related to the age of studied sites for which the cause of rejuvenating or getting older has not been clarified yet. Similar conclusions may be drawn from the analysis of results obtained in other laboratories (e.g. Kusiak et al., 2011). In such situations, it seems reasonable to assume that such false dating may result from specific properties of thermoluminescent minerals included in the dated samples (e.g. the sample from grave 125 has a very high equivalent dose and a very low year dose). However, confirmation or denial of this assumption requires separate studies.

\section{JAROSŁAW, SITE 158}

The site 158 in Jarosław was excavated in 2008. The exploration was carried out (Pelisiak and Bobak with the team) in connection with the planned construction of a ring road. The researchers studied the surface of 191 acres. They discovered 631 settlement features and a 
substantial number of stray finds coming from several prehistoric ages and periods, as well as historic times ${ }^{3}$.

An important fact is that one settlement has yielded the pottery of the late-phase of Tarnobrzeg Lusatian culture and the Pomeranian culture with elements very similar to the Jastorf style. Thus, the pottery of this horizon has been selected for TL analysis. The researchers have chosen 11 samples coming from nine features (Table 2).

Feature 5 - it was de facto an oval $(78 \times 39 \mathrm{~cm})$ cluster of the Pomeranian culture pottery. The researchers selected for dating a fragment coming from a dumpy potshaped vessel with a frilled rim (Fig. 7: 6). The rest of the inventory correlates with the final phase of the Pomeranian stylistics. Some of them are very similar to the Jastorf style. The obtained date $2352 \pm 166$ years [before 2010] corresponds to $508-176 \mathrm{BC}$.

Feature $22-$ it is a typical settlement oval-shaped feature $(160 \times 148 \mathrm{~cm})$ with a basin-shaped profile (depth $44 \mathrm{~cm}$ ). TL dating was obtained from a fragment of vessel made in the type of a profiled bowl with a defined rim (Fig. 7: 1). It was the only morphologically pronounced pottery fragment within the whole assemblage. The data indicates $2416 \pm 169$ years [before 2010] [575-237 BC].

Feature 58 - it was a quite large $(220 \times 160 \mathrm{~cm})$ feature with an irregular profile (depth $92 \mathrm{~cm}$ ). TL date, obtained from the middle part of a vase-shaped vessel (?) indicates $2684 \pm 188$ years [before 2010] [862-486 BC].

Feature 191 - it is a typical, oval $(184 \times 80 \mathrm{~cm})$ storage pit of a rectangular profile (depth $44 \mathrm{~cm}$ ). A fragment chosen for dating came from a profiled vessel $-\mathrm{a}$ vase or a bucket. The obtained date is $2805 \pm 196$ years [before 2010] [991-599 BC].

Feature 237 - it is also an oval $(125 \times 110 \mathrm{~cm})$ settlement pit with a slightly trapezoid profile (depth $26 \mathrm{~cm}$ ). The assemblage included among others the parts of an interesting large vase-shaped vessel with a plastic, horizontal handle attached below the coarse curve (Fig. 8: 1). Stylistics of this vessel is similar to the Upper Silesia - Lesser Poland materials. This precise piece of pottery provided the date $2851 \pm 200$ years [before 2010] [1041-641 BC].

Feature $354-$ it is also an oval $(130 \times 120 \mathrm{~cm})$ storage pit of a rectangular profile (depth $38 \mathrm{~cm}$ ). For dating a fragment of a large vase-shaped vessel with a biconical belly was selected, a smooth upper surface and a coarse surface below the curve (Fig. 8: 2). It obtained the date $2752 \pm 193$ years [before 2010] [935-549 BC].

Feature $386-$ it was also a similar $(105 \times 100 \mathrm{~cm})$ storage pit with a basin-shaped profile (depth $43 \mathrm{~cm}$ ). The obtained TL date came from a small pot-shaped vessel with a slightly flaring rim and a rough outer surface (Fig. 7: 5). The obtained date is $2832 \pm 198$ years [before 2010] [1020-624 BC].

\footnotetext{
${ }^{3}$ The whole collection of the materials coming from the site is being prepared for publication
}

Feature 495 - it was identified as a remain of large $(464 \times 189 \mathrm{~cm})$ feature, probably a dwelling, with a depth of $60 \mathrm{~cm}$. A relatively rich inventory of artefacts provided for the analysis fragments of two vessels: a vase of a biconical belly (Fig. 8: 3), and a profiled, decorated bowl (Fig. 7: 2). TL dates are, respectively: $2394 \pm 168$ and $2285 \pm 160$ years [before 2010] [552-216 and 435-115 $\mathrm{BC}$.

Feature 1252/1255 - it was registered as a stratigraphic system of a large oval feature $(310 \times 220 \mathrm{~cm})$ with a basin-shaped profile (depth $60 \mathrm{~cm}$ ) and a classic trapezoid pit of the Mierzanowice culture located underneath. The analysed samples were selected from a fragment of a flat cake-shaped plate (Fig. 7: 4) uncovered in the proper fill of the pit 1252, and a fragment of vessel discovered in the feature 1255 (located there in the secondary deposit), coming from a pot-shaped vessel with a frilled rim (Fig. $7: 3)$. Another piece of the same vessel was also found also in the proper pit 1252. Obtained TL dates are respectively $2418 \pm 169$ and $2115 \pm 148$ years [before 2010] [577$239 \mathrm{BC}$ and $253 \mathrm{BC}-43 \mathrm{AD}]$.
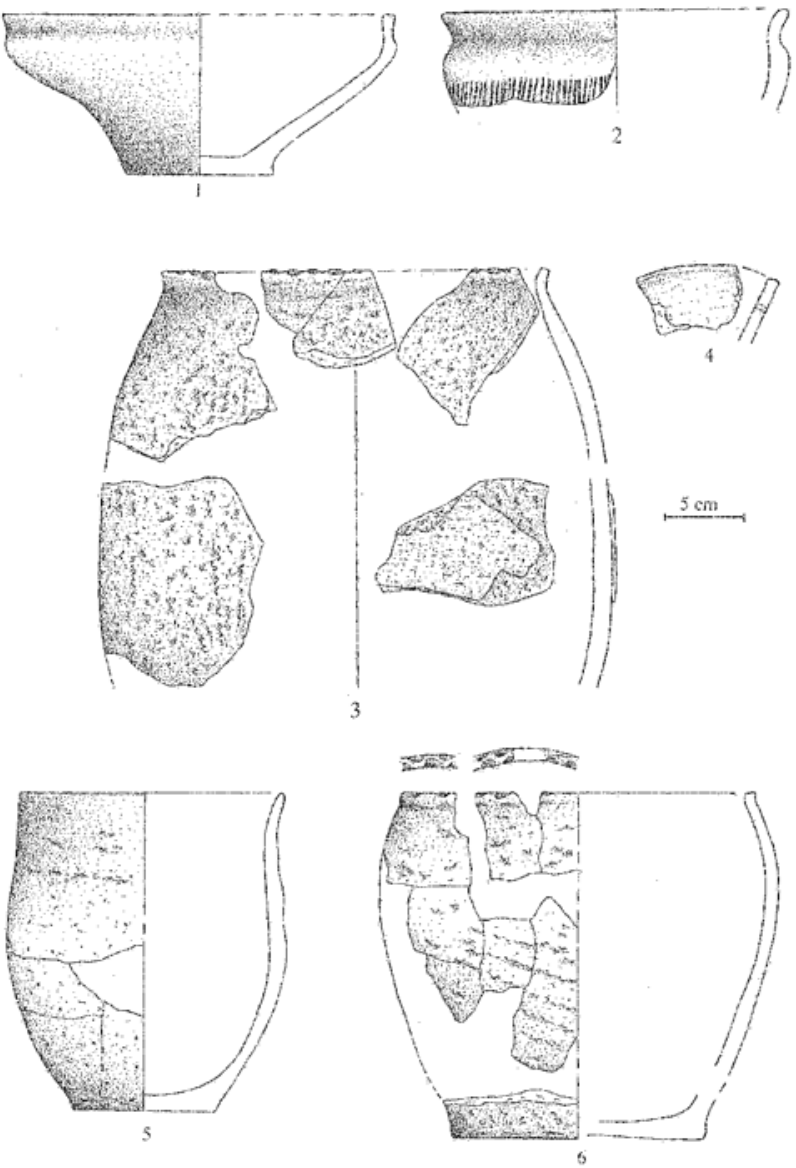

Fig. 7. Jarosław, dist. loco, site 158. Ceramics dated by TL method 1 - feature 22, 2 - feature 495, 3 - 1252/1255 feature, 4 - feature 1252 , 5 - feature 386, 6 - feature 5). 


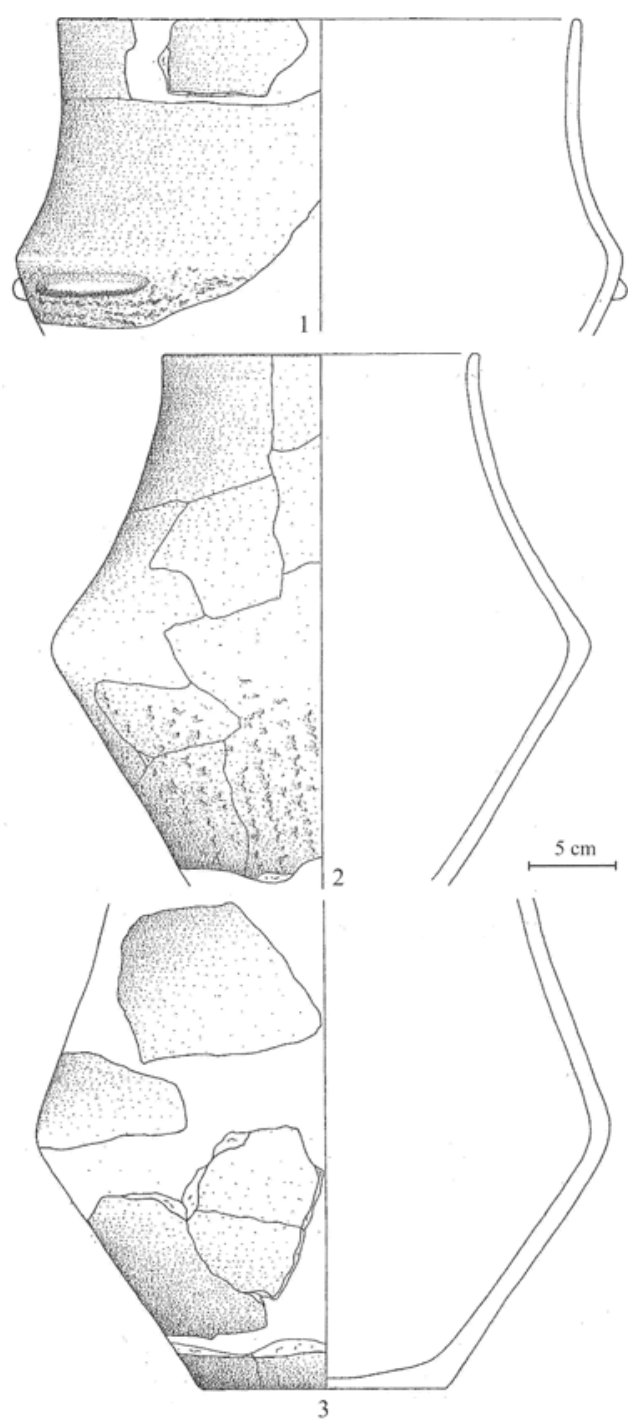

Fig. 8. Jarosław, dist. loco, site 158. Ceramics dated by TL method (1 - feature 237, 2 - feature 354, 3 - feature 495)

For TL dates the range of measurement error must be considered, which in our case equals 200-160 years. Distribution of measurement results (Fig. 9) clearly indicates two horizons - phases of an existing settlement. The first group of dates (features: 58, 191, 237, 354, 386) is connected with the Tarnobrzeg Lusatian culture. The second group (objects: 5, 22, 495 and 1252/1255) is associated with the Pomeranian culture and related materials. In this range the obtained TL dating confirms the correctness of the typological and technological analysis of stray finds. With regards to two features - 495 and 1252/1255 we have double TL dating. As the most probable (yet still only hypothetical) chronology of the features we may accept the common ranges of dates established for the same pits. However, considering the feature 495 it would be still a fairly long time interval $-435-216$ BC. Therefore, the most probable chronology of the feature would involve the end of the $5^{\text {th }}, 4^{\text {th }}$ and $3^{\text {rd }}$ century BC. It is obvious, that so wide dating span cannot be taken as the actual extent of "feature functioning" ${ }^{\text {. Consequently, }}$ there are at least two possible interpretations in this case. The specificity of the feature (large, fairly shallow) causes that we may deal with the material somehow mixed in the fill. The older date refers to the vase-shaped vessel, which may be associated with the Tarnobrzeg Lusatian culture, and the younger one, coming from the bowlshaped vessel with comb ornamentation, evidently refers to the Jastorf-La Tene materials, within the obvious context of the Pomeranian culture pottery. The second interpretation would emphasize the mixed nature of the pottery material as a result of some kind of the "TarnobrzegPomeranian" cultural syncretism.

The second feature $-1252 / 1255$ is less controversial. Common ranges of the two dates (577-239 $\mathrm{BC}$ and 253BC-43AD) indicate a very narrow chronological interval 252-239 BC. Undoubtedly, it is hard to assume that this 13-year period precisely indicates the chronology of the feature. We can only assume that the second half of $3^{\text {rd }}$ century $\mathrm{BC}$ is probable with regards to the existence of the final Pomeranian ceramic materials in this feature, which connections with the Czerniczyn group or widely understood circle of the Jastorf culture were identified.

The presented procedure for chronological clarifications on the basis of common TL dating ranges seems to be correct, although the results cannot be taken too literally. It should be remembered that we are considering short series of dating.

Three settlement features in Jarosław, which were dated by TL, were sampled also for radiocarbon dating. The results of ${ }^{14} \mathrm{C}$ dating are presented in Table 3. Their calibration is in fact ambiguous because of the flattening (the plateau) of the calibration curve ${ }^{5}$, which falls into approximately 740-420 BC (Walanus and Goslar 2009), hence it has a limited significance in absolute dating of archaeological materials and attempts to relate them to narrow chronological interval. The presented TL date margin of acceptance is $68 \%$, and thus it corresponds to a value $1 \sigma$ in the ${ }^{14} \mathrm{C}$ dating method. Therefore we are able to compare these two values (Fig. 10). We have received quite interesting results here. For the feature 386 its common range is a very narrow scope which falls from the end of the $8^{\text {th }}$ to the beginning of 7 th century $\mathrm{BC}$ (710-690). However, there is only $3.5 \%$ probability of correct determination of radiocarbon dating. With refer-

\footnotetext{
${ }^{4}$ For settlement features it is usually assumed that they were utilized for at most several dozens of years. In fact, this period might have been even shorter, owing to the way in which the pits were constructed and able to be used.

${ }^{5}$ The received larger series of radiocarbon dates for Hallstatt period features from the territory of south east Poland already enable us to compare and relate both archaeological artefacts as well as absolute dates received by other methods (TL, dendrochronology). A separate article will be devoted to this issue. Hopefully, this kind of research will lead to the neutralization of the wide scope of ${ }^{14} \mathrm{C}$ calibration curve plateau of the Early Iron Age.
} 


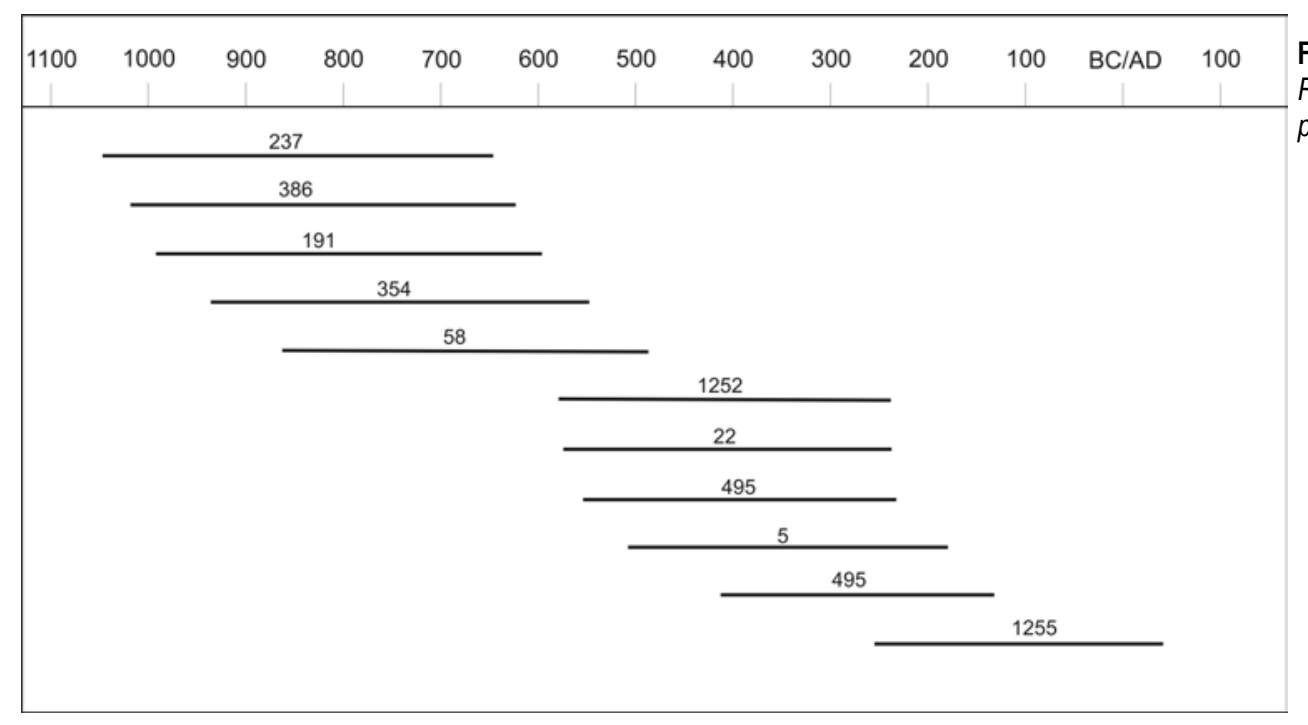

Fig. 9. Jarosław, dist. loco, site 158. Results of TL method (with 68\% probability range).

Table 3. List of radiocarbon dates for the features from site 158 in Jarosław, which are also dated by TL method.

\begin{tabular}{|c|c|c|c|c|}
\hline \multirow{2}{*}{$\begin{array}{c}\text { Feature } \\
\mid{ }^{14} \mathrm{C} \text { sample material }\end{array}$} & \multirow{2}{*}{ Sample No. } & \multirow{2}{*}{$\begin{array}{c}{ }^{14} \mathrm{C} \text { Age } \\
\text { (BP) }\end{array}$} & \multicolumn{2}{|c|}{ Calibrated Age (BC) } \\
\hline & & & range $68.2 \%$ & range $95.4 \%$ \\
\hline $\begin{array}{c}58 \\
\text { /charred plant remains }\end{array}$ & Poz-31703 & $2450 \pm 35$ & $\begin{array}{c}750(20.9 \%) 680 \\
670(6.2 \%) 640 \\
560(24.4 \%) 480 \\
470(16.7 \%) 410\end{array}$ & $\begin{array}{l}760(23.8 \%) 680 \\
670(71.6 \%) 400\end{array}$ \\
\hline $\begin{array}{c}191 \\
\text { /charred plant remains }\end{array}$ & Poz-31702 & $2445 \pm 30$ & $\begin{array}{c}740(18.2 \%) 690 \\
670(4.5 \%) 640 \\
550(25.9 \%) 480 \\
470(19.5 \%) 410\end{array}$ & $\begin{array}{l}760(23.7 \%) 680 \\
670(10.5 \%) 610 \\
600(61.2 \%) 400\end{array}$ \\
\hline $\begin{array}{c}386 \\
\text { /charred plant remains }\end{array}$ & Poz-31744 & $2420 \pm 35$ & $\begin{array}{c}710(3.5 \%) 690 \\
540(64.7 \%) 400\end{array}$ & $\begin{array}{c}750(16.8 \%) 680 \\
670(4.9 \%) 640 \\
600(73.4 \%) 390\end{array}$ \\
\hline
\end{tabular}

ence to two other features, the situation is not so clear. For the feature 191 its common ranges are two time intervals of the radiocarbon calibration determinations: 740-690 and 670-640 BC. Together it can range between mid- $8^{\text {th }}$ and mid- $7^{\text {th }}$ century $\mathrm{BC}$. The widest common range of indications was noticed in respect to the feature 58. There are 3 time intervals of calibrated radiocarbon determinations: 750-680, 670-640 and 560-480 BC. Total range is from mid- $8^{\text {th }}$ until the beginning of the $5^{\text {th }}$ century $\mathrm{BC}$.

Assessing the correctness of pits assignment to narrower time ranges should be carried out on the basis of archaeological material occurring there. Ceramics, as it is commonly understood, is not a good correlative in this case. However, there are other artefacts discovered in the pits at the site in Jarosław, where the dating procedure was conducted. It is worth mentioning a glass bead with "eyes" (made of yellow mass, decorated in four pairs of "eyes", which form concentric arrangements in blue and white colours), which two halves were found in the features 386 and 441. It represents type 533 of Venclová (1990). It is possible to date it at a fairly broad chronolog-

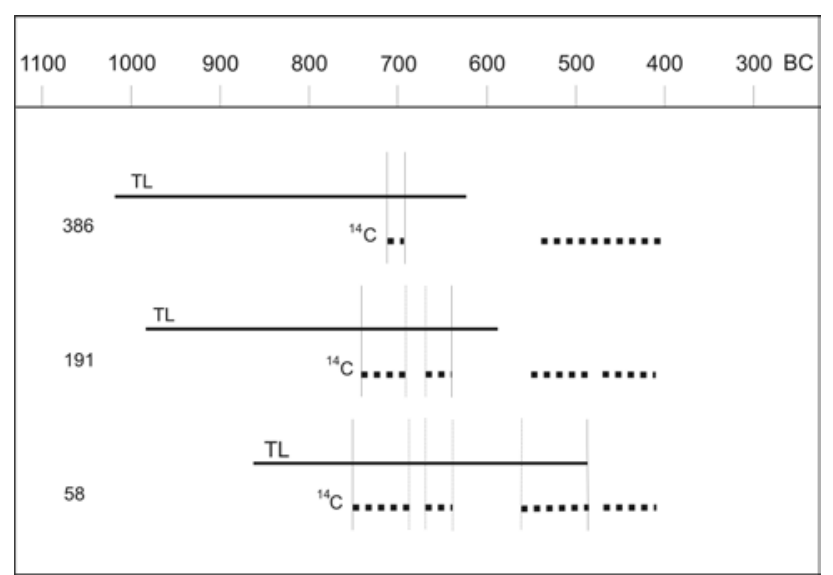

Fig. 10. Jarosław, dist.loco, site 158. Comparison of $T L$ and ${ }^{14} \mathrm{C}$ dating for selected features. 
ical framework from $\mathrm{HaD}$ to $\mathrm{LtD}$, but the most numerous occurrence was noticed in the oldest part of this range, i.e., HaD and LtA (Venclová 1990), which means the period from the end of $7^{\text {th }}$ to $5^{\text {th }}$ century BC. Such chronology does not allow us to correlate it effortlessly with $\mathrm{TL}$ and ${ }^{14} \mathrm{C}$ dating (Table 4).

However, the most likely is in this context the recognition of the convergence of radiocarbon (almost 65\% margin of acceptance) and typological dating, which allow us to relate the feature with the period from the end of the $6^{\text {th }}$ to $5^{\text {th }}$ century BC. Significantly older TL date brings remarkable complications. If we assume its correctness, the dated pottery should be regarded as an older item which appeared in the features fill as the secondary deposit, but within the same cultural entity. Thus, the entire content should not have been treated as a homogeneous set and with regards to not very deep settlement features, the fact seems obvious.

\section{CONCLUSIONS}

To put it briefly, we may say that the cases described in the article are the first attempt to date the ceramics from the late Bronze Age and early Iron Age discovered in south-eastern Poland by means of TL dating. Ten dates were received for the cemetery in Kłyżów, while 11 dates - for the settlement in Jarosław. A relatively weak point of this method here is a large range of measurement error. That is why, literally, the examples described in the article do not play a significant role in a very precise dating of materials, which usually expects an archaeologist. However, it seems that both sites proved their necessity for solving specific research problems (Kłyżów - an attempt to recognize relative chronology of clusters of graves; Jarosław - separating hardly identifiable features of the Tarnobrzeg Lusatian culture and the Pomeranian culture). Interpretation of the TL dates must be associated with a thorough archaeological (stylistic-chronological) analysis of dated pottery. Only under such circumstances this method will become an additional tool that may be helpful in the stratification of materials and/or determining the differences in their relative chronology within a given site. The presented example from Jarosław also points out the possibility of clarifying the chronology of the features by $\mathrm{TL}$ and ${ }^{14} \mathrm{C}$ cross-dating in ambiguous situations in case of radiocarbon dates calibration. Con-

Table 4. Comparison of the absolute dating for the feature 386 by means of various methods (radiocarbon and TL dates are presented in the range of probability $1 \sigma)$.

\begin{tabular}{|c|c|c|c|c|c|c|}
\hline Object 386 & XI & $X$ & IX & VIII & VII & VI \\
\hline TL Dating & & -..-. & 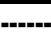 & 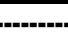 & - n & \\
\hline${ }^{14} \mathrm{C}$ Dating & & & & -- & & 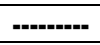 \\
\hline Typology - the bead & & & & & $-\cdots$ & 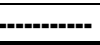 \\
\hline
\end{tabular}

sidering the examination of TL date ranges, it provides similar opportunities for a few samples coming from the same feature. For the period of the early Iron Age every method which may lead to specification of dating of archaeological material is worth considering. Typological dating of some of the artefacts (especially brooches), which in the Middle European archaeology constitute the primary source for any type of chronological analysis, is gradually becoming more important. Lack of such artefacts in the south-east Poland forces us to look for different analytical methods, hence the attempt to employ TL. It seems to be so promising that it may mark the beginning of a wider research program, which would consider all available methods, both those that are traditionally employed by archaeologists (typology, stratigraphy), as well as those offered by other scientists $\left({ }^{14} \mathrm{C}\right.$, TL, dendrochronolgy).

\section{REFERENCES}

Adamiec G and Aitken MJ, 1998. Dose-rate conversion factors: update. Ancient TL 16(2): 37-50.

Bailiff IK, 2007. Methodological developments in the luminescence dating of brick from English late medieval and post medieval buildings. Archaeometry 49(4): 827-851, DOI 10.1111/j.14754754.2007.00338.x.

Barnett SM, 1999. Data list 6: luminescence dates for Late Bronze Age and Iron Age pottery assemblages in eastern and northern Britain. Ancient TL 17(1): 23-40.

Barnett SM, 2000. Luminescence dating of pottery from later prehistoric Britain. Archaeometry 42(2): 431-457, DOI 10.1111/j.14754754.2000.tb00892.x.

Benea V, Vandenberghe D, Timar A, Van den Haute P, Cosma C, Gligor M and Florescu C, 2007. Luminescence dating of Neolithic ceramics from Lumea Noua, Romania. Geochronometria 28: 9-16, DOI 10.2478/v10003-007-0027-9.

Blain S, Guibert P, Prigent D, Lanos P, Oberlin C, Sapin C, Bouvier A and Dufresne P, 2011. Combined dating methods applied to building archaeology: The contribution of thermoluminescence to the case of the Bell Tower of St Martin's Church, Angers (France). Geochronometria 38(1): 55-63, DOI 10.2478/s13386-011-0010-0.

Bluszcz A, 1989. Datowanie ceramiki metodą termoluminescencyjną (Thermoluminescence dating of pottery). Geochronometria 6: 193201 (in Polish).

Bluszcz A and Adamiec G, 1994. Termoluminescencyjne datowanie neolitycznej ceramiki z terenu Małopolski (okolice Kazimierzy Wielkiej) (Thermoluminescence dating of the Neolithic pottery from the Małopolska region (the environs of Kazimierza Wielka)). Światowit 39: 157-181 (in Polish).

Bluszcz A and Pazdur MF, 1994a. Datowanie metodą termoluminescencyjną zabytkowej ceramiki z grodziska w Haćkach na Podlasiu (Thermoluminescence dating of pottery from settlement in Haćki village on Podlasie). Geochronometria 9: 47-67 (in Polish).

Bluszcz A and Pazdur MF, 1994b. Porównanie typologiczne datowania ceramiki z wynikami fizycznych metod datowania (Comparison of the typological dating of ceramics with the results of physical dating methods). Światowit 39: 182-192 (in Polish).

Buko A, Dzieńkowski T and Kusiak J, 2008. Próba datowania ceramiki wczesnośredniowiecznej metodą termoluminescencyjną: przykład badań zespołu grodowego w Busównie (Dating Early Medieval ceramics by the thermoluminescence method: Busówno site case stady). Archeologia Polski 53, 1: 25-49 (in Polish).

Chruścińska A, Jesionowski B, Oczkowski HL and Przegiętka KR, 2008. Using the TL single-aliquot regenerative-dose protocol for the verification of the chronology of the Teutonic Order Castle in 
Malbork. Geochronometria 30: 61-67, DOI 10.2478/v10003-0080006-9.

Czopek S, 1992. Zabytki żelazne w materiałach grupy tarnobrzeskiej (The Tarnobrzeg group iron artefacts). W: Czopek S, red, Ziemie polskie we wczesnej epoce żelaza i ich powiazania z innymi terenami (In: Czopek S, ed, Polish territories in the early Iron Age and their connections with other lands). Rzeszów: 109-126 (in Polish).

Czopek S, 1996. Kolczyki typu Kłyżów (Kłyżów type earrings). W: Chochorowski J, red, Problemy epoki brązu $i$ wczesnej epoki żelaza w Europie Środkowe. Księga jubileuszowa poświęcona Markowi Gedlowij (In: Chochorowski J., ed, Problems of the Bronze Age and early Iron Age in Central Europe. Jubilee book dedicated to Marek Gedl). Kraków: 163-173 (in Polish).

Czopek S, 2001. Pysznica pow. Stalowa Wola, stanowisko 1 - cmentarzysko ciałopalne z przełomu epok brązu i żelaza (Pysznica, district Stalowa Wola; site 1 - the late Bronze and early Iron Age cremation cemetery). Rzeszów (in Polish).

Czopek S, 2007. Grodzisko Dolne, stanowisko 22 - wielokulturowe stanowisko nad dolnym Wisłokiem, cześć I - od epoki kamienia do wczesnej epoki żelaza (Grodzisko Dolne, site 22 - a multicultural site on the lower Wisłok river. Part I - from the Stone Age to the early Iron Age). Rzeszów (in Polish).

Czopek S and Poradyło W, 2008. Warzyce, pow. Jasło, stan. 17 - osada z epoki brązu i wczesnej epoki żelaza (Warzyce, District Jaslo, site 17 - a settlement from the Bronze Age and Early Iron Age). Rzeszów (in Polish).

Daniels F, Boyd CA and Saunders DF, 1953. Thermoluminescence as a research tool. Science 117(3040): 343-349, DOI 10.1126/science.117.3040.343.

Dąbrowski J, 2009. Polska przed trzema tysiacami lat. Czasy kultury łużyckiej (Poland three thousand years ago. The Lusatian culture and its times). Warszawa (in Polish).

Feathers JK, 2003. Use of luminescence dating in archaeology. Measurement Science and Technology 14(9): 1493-1509, DOI 10.1088/0957-0233/14/9/302.

Fleming S, 1979. Thermoluminescence techniques in archaeology. 233 $\mathrm{pp}$

Gedl M, 1989. Wstep (Intoduction). W: Kmieciński J, red, Pradzieje ziem polskich, t. I, cz. II Epoka brązu początki epoki żelaza (In: Kmieciński J., ed, Prehistory of Polish territories, volume I, part II. Bronze Age and early Iron Age). Warszawa-Łodź: 393-400 (in Polish).

Grögler N, Houtermans FG and Stauffer H, 1958. Radiation damage as a research tool for geology and prehistory. 5a Rass Internazion Elettr Nucl Sezione Nucleare Rome: 5-15.

Huntley DJ and Lamothe M, 2001. Ubiquity of anomalous fading in Kfeldspars and the measurement and correction for it in optical dating. Canadian Journal of Earth Science 38(7): 1093-1106, DOI 10.1139/e01-013.

Kostrzewski J, 1949. Pradzieje Polski (Prehistory of Poland). Poznań (in Polish).

Kusiak J, 2011. Perspektywy wykorzystania metody termoluminescencyjnej w datowaniu obiektów wczesnośredniowiecznych w oparciu o wyniki analiz dla stanowiska w Nowińcu (gm. Lubsko, woj. lubuskie) (Prospects of thermoluminescence method used for dating of Early Middle Ages objects based on the results obtained for the Nowiniec site (Lubsko district, Lubuskie province). W: Gruszka B. red. Nowiniec stanowisko 2 - wczesnośredniowieczne grodzisko na pograniczu ślasko-tużyckim w świetle badań interdyscyplinarnych. (In: Gruszka B. ed. Nowiniec, site 2 Early Middle Ages hillfort in the borderland between Silesia and Lusatia in the light of interdisciplinary research). Zielona Góra (in Polish): 203-210.

Kusiak J, Łanczont M, Dzieńkowski T and Rychter M, 2009. Nowe możliwości zastosowania metody datowania termoluminescencyjnego w badaniach archeologicznych (New opportunities for application of the thermoluminescence dating method in archaeological studies). W: Paner H, red, Aktualne problemy epoki kamienia na Pomorzu (In: Paner H, ed, Current problems of the Stone Age in Pomerania). Muzeum Archeologiczne w Gdańsku: 165-170 (in Polish).

Kusiak J, Rychter M and Stasiak-Cyran M, 2011. Attempts at thermoluminescence dating of fired materials from the Przeworsk Culture settlements. Geochronometria 38(4): 359-368, DOI 10.2478/s13386-011-0026-5.

Mejdahl V and Wintle AG, 1984. Thermoluminescence applied to age determination in archaeology and geology. In: Horowitz YS, ed, Thermoluminescence and thermoluminescent dosimetry, Boca Raton, CRC Press, v. III: 133-190.

Olley JM, Murray A and Roberts GR, 1996. The effects of disequilibria in the uranium and thorium decay chains on burial dose rates in fluvial sediments. Quaternary Science Reviews 15(7): 751-760, DOI 10.1016/0277-3791(96)00026-1.

Polymeris GS, Sakalis A, Papadopoulou D, Dallas G, Kitis G and Tsirliganis NC, 2007. Firing temperature of pottery using TL and OSL techniques. Nuclear Instruments and Methods in Physics Research 580(1): 747-750, DOI 10.1016/j.nima.2007.05.139.

Poręba GJ and Fedorowicz S, 2005. Gamma spectrometry for OSL and TL dating of loess deposits at Dybawka and Tarnawce (SE Poland). Geochronometria 24: 27-32.

Prescott JR and Hutton JT, 1994. Cosmic ray contributions to dose rates for luminescence and ESR dating: large depths and long-term time variations. Radiation Measurements 23(2-3): 497-500, DOI 10.1016/1350-4487(94)90086-8.

Preusser F, Degering D, Fuchs M, Hilgers A, Kadereit A, Klasen N, Krbetschek M, Richter D and Spencer JQG, 2008. Luminescence dating: basics, methods and applications. Eiszeitalter und Gegenwart Quaternary Science Journal 57(1-2): 95-149.

Przybyła MS, 2003. Uwagi o chronologii ceramiki grupy tarnobrzeskiej (Comments on chronology of the Tarnobrzeg group pottery), Materiały i Sprawozdania Rzeszowskiego Ośrodka Archeologicznego (Materials and Reports of Rzeszów Archaeological Centre), 24: 27-54 (In Polish).

Roque C, Guibert P, Vartanian E, Vieillevigne and Bechtel F, 2004. Changes in luminescence properties induced by thermal tratments; a case study at Sipan and Trujillo Moche sites (Peru). Radiation Measurements 38(1): 119-126, DOI 10.1016/S13504487(03)00249-X.

Sánchez JS, Mosquera DF and Fenollós JLM, 2008. TL AND OSL dating of sediment and pottery from two Syrian archaeological sites. Geochronometria 31: 21-29, DOI 10.2478/v10003-0080017-6.

Szarek-Waszkowska E, 1975a. Cmentarzysko łużyckie w Kłyżowie, woj. tarnobrzeskie. Komentarz wystawy (The Lusatian cemetery in Kłyżów, Tarnobrzeg voivodeship. An exhibition commentary). Rzeszów (in Polish).

Szarek-Waszkowska E, 1975b. Kłyżów, pow. Stalowa Wola, stanowisko 2, Informator Archeologiczny (Kłyżów, district Stalowa Wola, site). Warszawa: 88 (in Polish).

Trachsel M, 2004. Untersuchungen zur relativen und absoluten Chronologie der Hallstattzeit, Universitätsforschungen zur Prähistorischen Archäologie, Bd. 104, Bonn (in German).

Trybała-Zawiślak K, 2005. Komunikat o ciałopalnym cmentarzysku tarnobrzeskiej kultury łużyckiej na stanowisku 2 w Kłyżowie (Announcement about the Lusatian culture cremation cemetery at site 2 in Kłyżów). W: Kuraś M, red, Archeologia Kotliny Sandomierskiej. Rocznik Muzeum Regionalnego w Stalowej Woli, nr 4, monograficzny (In: Kuraś M, ed, Annals of Regional Museum in Stalowa Wola, No. 4 monographic book). Stalowa Wola: 411-422 (in Polish).

Venclová N, 1990. Prehistoric glass in Bohemia. Praha.

Walanus A and Goslar T, 2009. Datowanie radiowęglowe (Radiocarbon dating). Kraków: 147 pp. (in Polish).

Wintle AG, 2008. Fifty years of luminescence dating. Archaeometry 50(2): 276-312, DOI 10.1111/j.1475-4754.2008.00392.x.

Zink A and Porto E, 2005. Luminescence dating of the Tanagra terracottas of the Louvre collections. Geochronometria 24: 21-26. 